\title{
ENGINEERING THE FUTURE: TEACHING READING AND WRITING AT THE UNIVERSIDAD NACIONAL DE ENTRE RIOS
}

\author{
Diana Monica Waigandt \\ National University of Entre Rios \\ Concepción del Uruguay, AR \\ Alicia Maria Noceti* \\ National University of Entre Rios \\ Concepción del Uruguay, AR \\ Luz Marina Zapata ${ }^{* * *}$ \\ National University of Entre Rios \\ Concepción del Uruguay, AR
}

\begin{abstract}
Since the 1990s, in Argentina there has been considerable concern over whether higher education institutions must undertake the responsibility of teaching academic skills to their student population or if both undergraduates and graduates ought to cope with the enculturation process without assistance. Although academics seem to have reached an agreement and have put forward a number of actions aimed at facilitating the access of university students into their target discourse communities, there is still heated debate about how the issue must be approached. In this article we describe the initiatives carried out at two engineering colleges: the Facultad de Ciencias de la Alimentación and the Facultad de Ingeniería belonging to the Universidad Nacional de Entre Ríos that have paved the way for the inclusion of academic literacy development in the curriculum.

Keywords: Academic Literacy Development; Engineering Education; Reading and Writing in Context; Reading and Writing Across the Curriculum.
\end{abstract}

\section{Introduction}

Higher education in Argentina is a heterogeneous and complex system made up of over a hundred higher education institutions, both state-run and private, that are spread all over the national territory to provide scientific, professional, humanistic and technical training to more than 1,500,000 students.

The Argentinean higher education system goes back to the colonial period and has its roots in the old
Spanish higher education system which is basically a continental education system. In 1918, a highly popular series of reforms took place in the oldest university of the country - the Universidad de Córdoba - that brought about the modernization of the system as it is known today. The main changes of the Reforma del 18 can be summarized as follows: 1) University autonomy, i.e. the right for each university and college to choose their own government, academic staff and studies without the intervention of the national government or

\footnotetext{
* Professor of English at the Department of Humanities and Languages, at Universidad Nacional de Entre Ríos. She is carrying out a research project concerning the teaching of mathematics to future bioengineers with a strong emphasis on formative assessment. Master in Teaching English as a Foreign Language (Universidad de Jaen - España). Her email address is dwaigandt@ingenieria.uner.edu.ar

** Alicia Maria Noceti is a professor and researcher at the School of Food Engineering, at Universidad Nacional de Entre Rios. She is currently performing research on engineering students' written production of genres with a particular focus on the title and abstract of their theses. Her email address is nocetia@fcal.uner.edu.ar

${ }^{* * *}$ Associate Professor of Organic Chemistry at Universidad Nacional de Entre Ríos. PhD in Science, Technology and Food Management (Universidad Politecnica
} de Valencia - España). Her email address is zapatam@fcal.uner.edu.ar 
any other organism; 2) open admission (education as a right as a result of the fact that entry is unrestricted and not competitive); 3) access to teaching by public competition, i.e. the selection of faculty is carried out through open, competitive examinations in order to counteract nepotism and patronage, and promotion of professors is based on merit and achievement rather than seniority); 4) academic freedom; 5) acknowledgment of democratically elected student unions and co-governance. This led to new governance structures through the conformation of local councils in the case of colleges (consejo directivo) and the superior council that is each university's executive governing body (consejo superior). Both types of councils are made up of representatives from all the parties (alumni, students, academic staff and administrative \& service personnel).

Since its foundation, higher education in our country has focused on the teaching of professions and can be divided into three levels:

- Higher education institutes that include studies which offer short vocational programmes and academic education (i.e. teacher training) at the undergraduate level.

- Universities and university institutes consisting of professional education programmes offering degrees in engineering, medicine, law, architecture, among others, that can take between five to six years to complete.

- The postgraduate level which is specialized and research-oriented and aims at achieving master and doctoral degrees.

With the exception of short democratic periods, the national universities were under the control of successive military dictatorships, and they did not regain their autonomy until the reestablishment of democracy in 1984.

In the early 1990s, within an "international agenda for the modernization of higher education systems" (Marginson \& Mollis, 2001) the controversial Higher
Education Law $\left(\mathrm{N}^{\circ} 24,521\right)$ was passed. It extended the reach of reform to all institutions of higher learning, including university and non-university tertiary-level institutions and created central bodies to evaluate and accredit university institutions (i.e. the University Policies Secretariat (SPU) and the National Commission for University Evaluation and Accreditation-CONEAU). Although this detailed and comprehensive reform was implemented without major difficulties, certain articles of the Higher Education Law, such as restrictions of student participation in the governing system or authorization to charge fees, generated legal challenges, institutional conflicts and even violent confrontations with the police.

At the end of 2015, several modifications to the polemical law were finally approved. These ensure that education at the undergraduate level is tuition-free and open to everyone in state-run universities (also known as national or public universities) in accordance with the prevailing discourse associated with ideals of social justice and equality of opportunity.

In this context, approximately 80 percent of the total student population chooses among the 50 universities and 7 university institutes to undertake undergraduate studies (SPU, 2013). Unfortunately, a steady degradation of both primary and secondary education systems has opened up a gap between the required level to begin university studies and the level achieved by the end of secondary education. As there is no national secondary school-leaving examination, some universities, such as the Universidad de Buenos Aires (UBA), have created a one-year shared programme called Ciclo Básico Común $(C B C)$ to cope with this issue instead of administering selective entrance tests. Since 1985, students who choose to study at the UBA must complete the CBC programme before joining specific professional studies. Other national universities, on the other hand, offer short leveling entrance courses that may or may not be an entrance requirement.

Nonetheless, first-year dropout rates have been as high as $60 \%$ in addition to a graduation rate that in 2007 scarcely reached around 20\% (Chiroleu \& Marquina, 2010). The reasons behind this fact are varied and elusive. Students are heterogeneous according to their 
socioeconomic backgrounds, prior academic training, skills and behaviour. A number of actions have been taken to counteract these disparities. For instance, to help the students from more socially vulnerable groups, an increasing number of targeted retention scholarships are offered by the Ministry of Education ${ }^{1}$ and some provinces ${ }^{2}$. But, despite these efforts, living expenses for those students who must leave their home town to attend college can be burdensome. In other cases, even if parents manage to meet these living and instructional costs, societal factors encroach upon the young adult who seeks work that requires little or no training and will, in many cases, sacrifice his/her studies in favour of employment. From the academic point of view, the uneven distribution of cultural capital and, in many cases, the lack of family experience in higher education can be barriers to achieving success in college. These differences in student profile present challenges to the traditional ways in which higher education has been and, in many cases, is still being provided. In this sense, attention needs to be given to how students understand their relationship to their programme of study, a field that involves issues of identity and belonging. Moreover, the ways teaching and assessment are approached in different subjects can either help overcome or negatively affect the strangeness that novice members feel during the process of becoming part of the academic community. In this sense, academic literacy development is a key issue that can tip the scales in favour of the democratization of knowledge, inclusivity and social respect.

Academic literacy is a highly complex and multidimensional construct that reflects notions of multiplicity of practices, contexts, genres, identities and meanings (Street, 1993; Gee, 1990). From this perspective, literacy is best understood as a set of purposeful sociocultural practices that can be inferred from events mediated by written texts. These practices are patterned by social institutions and power relationships. Moreover, literacy is historically situated, which brings about change in visibility, dominance and influence. For pedagogical purposes, this social view of the term constitutes a significant shift from the early "study skills" model considered to be remedial, not inclusive and divorced from subject knowledge and allows for the dialogue and collaboration across approaches that focus on the different aspects that conform the academic literacy development process: a) language and grammatical competence (analysis and critique of texts); b) enculturation of students into discipline-specific discourses and genres; c) critical examination of institutional practices, rules and dominant discourses of the academy. We believe that college-level academic literacy, therefore, can only be conceived by the close interrelationship of its linguistic, cultural, and social dimensions.

In the following section we will refer to the actions that have been taken in the Argentinean state higher education system to foster the development of academic literacy.

\section{Literacy Development in Argentina's Higher Education}

Literacy in higher education becomes an enormous challenge for students as they are immersed into a completely new culture with its own conventions, mechanisms of intercommunication and participation, modes of belonging, ways of acting and a whole repertoire of genres that distribute knowledge among members of the target discourse community (Swales, 1990). College students must complete a variety of reading and writing tasks as they work toward their chosen degree. In fact, in college, undergraduate students learn and are assessed through reading and writing activities in almost all the content subjects. Moreover, at the graduate level, writing a final project, a dissertation or a thesis is a due academic process students must go through to attain their degree.

Since the 1990s, in Argentina there has been considerable concern over whether higher education institutions must undertake the responsibility of teaching academic skills to their student population or if both undergraduates and graduates ought to cope with the enculturation process without assistance. Advocates of the former position have put forward a number of initiatives within the Argentinean state university system aimed at facilitating students' enculturation into 
disciplinary communities and at decreasing dropout rates. In this regard, the establishment of the Unitwin UNESCO Chair on Reading and Writing in Latin America $^{3}$ at the Universidad del Valle (Colombia) was a vital step that has enabled collaboration between nine countries and more than thirty universities (Bolivar \& Parodi, 2015). The Universidad de Buenos Aires and other Argentinean national universities are members of this regional network for the improvement of education quality and equity under the leadership of Dr. Elvira Arnoux. Her pioneering work in the field of applied linguistics for the advancement of reading and writing in higher education has paved the way for the creation of workshops aimed at helping school leavers enter tertiary education (Arnoux et al., 1998), for the publication of manuals (Narvaja de Arnoux et al., 2002) and for reflection upon the teaching-learning process involved in academic writing (Arnoux, 2006; Arnoux et al., 1996).

Another significant milestone in generating interest in reading and writing in Argentina and Latin America was the creation of the GICEOLEM ${ }^{4}$, a multidisciplinary research group at the Instituto de Linguística (Universidad de Buenos Aires). Its leading researcher, Dr. Paula Carlino, and her team have developed a research programme to explore conceptions and practices in reading and writing in different disciplines at the secondary, higher education and postgraduate levels. What is more, Carlino's article "Academic Literacy: A Necessary Change, Some Possible Alternatives" (Carlino, 2003) has been of central importance as it led to the establishment of the field, provided the scholarly community with fresh insight into the concept of academic literacy, and stimulated the advancement of a variety of actions in favour of the development of academic literacy in leading Argentinean universities. Many of these were reported by Carlino (2006) and, since then, other initiatives have followed (Alzari et al., 2014; Amieva, 2014; Añino et al., 2012; Arnoux, 2008, 2009, 2011, 2015; Carlino, 2013, 2014; Pipkin Embón \& Reynoso, 2010).

More than a decade later, although academics in our country seem to have reached an agreement and have undertaken responsibility for supporting students with the transition process from previous educational contexts to that of tertiary education, there is still heated debate about how the issue must be approached (Carlino, 2013). In this sense, the organization of isolated workshops, for example, are remedial actions as they tend to keep the development of academic skills on the margin or outside the curriculum instead of being integrated with it (Carlino, 2012). Furthermore, workshops for students and teachers are usually generic in content and do not recognize or neglect the varying requirements of the disciplines (Skillen et al., 1998).

In "Academic Literacy Ten Years Later"5 Carlino (2013) reformulates and enriches her definition of academic literacy. While her first definition denoted a) the specific ways in which texts should be used to conform to the expectations of the different academic communities, and $b$ ) the learning process that students undergo to become participants of those communities, in her renewed characterization of academic literacy, Carlino highlights that the work of teachers and educational institutions is a vital part of the process and that it is impossible to succeed by means of a single course or through activities that isolate reading and writing practices. Teaching in context involves reading and writing the genres that are actually read and written for the study program as well as offering students the possibility of performing full and meaningful reading and writing practices. In other words, college students must be assisted in all subjects and throughout the programme of study and learn to not only read and write as specialists do, but also to read and write to acquire specialist knowledge.

From this point of view, research findings on genres in academic and research settings (Swales, 1990), genres as social action (Bazerman, 1988; Freedman, 1994; Miller, 1984), situated learning (Brown, Collins \& Duguid, 1989; Lave \& Wenger, 1991), reading and writing as social activities or practices (Artemeva, 2008; Lea \& Street, 1998; Russell, 1990); teaching reading and writing in context (Chalmers \& Fuller, 1996; Purser et al., 2008; Radloff, 1998; Skillen et al., 1998) and the writing across the curriculum movement (WAC) (Bazerman et al., 2005; Russell, 2002) have become of paramount importance for scholars and institutions 
who are designing programmes to improve students literacy and learning outcomes.

In this regard, if an initiative is in line with situated cognition theories (Brown et al., 1989) and reading and writing are viewed as social practice (Miller, 1984), academic literacy can be acquired by actual participation of the learners. During the students' displacement from the periphery towards core positions at the center of the particular community of practice (Lave \& Wenger, 1991), they begin to master a shared repertoire of genres by doing things with and learning from experts. Thus, their sense of belonging develops while their acquaintance with discourse practices and engagement with the community strengthen.

It is also important to pay attention to the language used in the different disciplines. Thus, collaborative activities between discipline and discourse specialists enable the acquisition of genres from a socio rhetorical perspective (Bazerman, 1988; Freedman, 1994). This process of enculturation involves learning to produce genres with a specific objective in order to participate in typical recurrent discourse activities that circulate knowledge within a disciplinary community (Carlino, 2013).

The Programa de Desarrollo de Habilidades de Lectura y Escritura Académica a lo largo de la Carrera (PRODEAC) ${ }^{6}$ carried out at the Universidad de General Sarmiento since 2005 (Moyano \& Natale, 2012) is a successful example of this sort of institutional initiative in our country. This programme encourages teachers of all subjects to work along with a discourse specialist for some time in order to analyze the specific writing tasks students are expected to carry out. Similarly, many other initiatives are being carried out elsewhere in our country, sometimes with little or no institutional support. However, these efforts of teachers and researchers have paved the way for the consolidation of a field of action and thought that has gradually situated academic reading and writing at the center of the learning process in Argentinean academic contexts.

In the following section we will survey the actions undertaken at two engineering colleges belonging to the Universidad Nacional de Entre Rios where we have been teaching and researching for approximately twenty years.
Initiatives Aiming at Academic Literacy Development at Two Engineering Colleges Belonging to the Universidad Nacional De Entre Rios

Founded on May 10, 1973, the Universidad Nacional de Entre Ríos (UNER) ${ }^{7}$ is a relatively young national university that is made up of nine colleges situated in different towns of the Entre Ríos Province: Facultad de Ciencias de la Salud, Facultad de Bromatología, Facultad de Ciencias de la Administración and Facultad de Ciencias de la Alimentación on the Uruguay River coast, and Facultad de Ciencias de la Educación, Facultad de Trabajo Social, Facultad de Ciencias Económicas, Facultad de Ciencias Agropecuarias and Facultad de Ingeniería on the Paraná River coast.

The Facultad de Ciencias de la Alimentación is located in Concordia, on the east coast of the Entre Ríos Province, while the Facultad de Ingeniería is located in Oro Verde, a small town on the west coast, at about 10 $\mathrm{km}$ from Paraná, the capital of the Province. They both offer engineering programmes and, consequently, share common goals and problems, such as high dropout and failure rates in the first years. As we have already discussed in the previous section, efforts in favour of academic literacy development over the duration of the programme of study can help counterbalance and even overcome these problems.

As can be seen from records of the Jornadas de capacitación sobre lectura y escritura en la universidad ${ }^{8}$ that took place in Oro Verde in 2014, on occasion of Dr. Charles Bazerman's visit to the UNER, teachers and researchers from the different colleges are working on mother tongue (L1) and foreign languages (L2) English, French and Portuguese - academic literacy development. However, in this article we will refer exclusively to the activities that the Facultad de Ciencias de la Alimentación and the Facultad de Ingeniería have been committed to in order to offer higher-quality, inclusive education.

Both colleges share a common framework of reference to follow as most of the engineering colleges in Argentina are represented by the Federal Council of Engineering Deans of Argentina (Consejo Federal de Decanos de Ingeniería de Argentina - CONFEDI) who signed the First Agreement on Generic Skills in 2006 
and the Declaration of Valparaíso on Generic Skills for Ibero-American Engineers in 2013. ${ }^{9}$ The technological and social skills that all graduates must develop before graduation are listed in both documents. Among the latter, the "ability to communicate effectively" includes writing rigorous and convincing technical texts (descriptive, argumentative, explicative), that accordingly take the communicative context into account. What is more, in 2012, the Argentinean national government set up the 2012-2016 Strategic Plan to Foster Engineering Training (Plan Estratégico de Formación de Ingenieros - PEFI 2016) ${ }^{10}$ to address the need for increased numbers of engineering graduates. This plan includes a project to encourage engineering students' graduation (Proyecto Delta $\mathrm{G}-\Delta \mathrm{G}$ ) that was launched in 2014 by the University Policies Secretariat belonging to the Ministry of Education (Secretaría de Políticas Universitarias - SPU - Ministerio de Educación). The $\Delta \mathrm{G}$ Project aims at increasing the graduation of advanced students that have discontinued their previous studies, must still pass between one and four academic activities to graduate, and are employed or self-employed.

In the following sections we will describe the activities that are carried out to foster the development of academic literacy both in L1 and in L2 at the two Facultades.

\section{Facultad de Ciencias de la Alimentación}

In this section of the paper, we will chronologically describe all actions that have been carried out in the field of literacy (both in L1 and L2) to facilitate academic literacy development of food engineering undergraduate and graduate students.

English is nowadays the world's major language for the communication of research findings and it plays a key role in academic settings worldwide. Thus, in order to become a full member of the international academic world, undergraduate students from non Englishspeaking backgrounds who seek to enter this discourse community (Swales: 1990) need to not only become competent users of the English language in everyday social practices, but also understand and effectively master the ways in which information and knowledge are organized and communicated in the different disciplines they are studying.

In the higher formal Argentinean education system, foreign language courses usually focus on a single skill - reading comprehension - to equip students with the necessary tools to read specific material from different disciplines; that is, they do not study the target language for general purposes. These courses deal with English for Specific Purposes (ESP) and are thus concerned with those communication skills that are required for reading academic texts. Besides, they are aimed at an epistemological community that shares content schemata but that is not familiar with the discourse proper to the disciplines both in L1 and L2.

This almost unanimous decision has been made countrywide owing to two main reasons: firstly, English courses are seldom allotted more than between 100 and 150 hours in the curriculum and, secondly, because of low university budgets, a single teacher is generally responsible for the teaching of large classes.

English as a foreign language has been taught to Engineering undergraduates ever since our school was created as the Instituto de Tecnología de Alimentos by the Universidad Nacional del Litoral in 1970. It later became the School of Food Science, when the Universidad Nacional de Entre Ríos was founded in May 1973. It is within the English curricular space that reading in English and writing, both in L1 and L2, have always been encouraged.

In the 1970s, reading was the skill taught within the English for Specific Purposes tradition. At first, the English course was one year long, until the curriculum was lengthened and taught over three full years. Writing in L1 was encouraged in these English courses as students had to produce texts in response to different rubrics.

As for academic literacy development courses in L1, an elective course dealing with reading and writing has been offered in the first year since 1993. In addition, a one-term curricular subject, Introduction to Food Engineering, introduces students to some academic genres focusing on content rather than on genre characteristics.

In 2002, due to students' requirements (based on a needs analysis survey), the English Department 
decided to shift to teaching the four skills, aspiring to turn out A1 users as measured by the European framework for the teaching of languages. The new curricular design included three 60 -hour terms $\left(2^{\circ}, 3^{\circ}\right.$ and $4^{\circ}$ years) which were complemented by optional courses taught during the term without any curricular English courses. These electives were quickly and willingly accepted with a special timetable offered to encourage attendance.

In 2005, the genre analysis approach was adopted in English teaching. Prototypical genres that distribute academic knowledge were collected and taught explicitly along the three courses. Horizontal articulation with other subjects has always been of utmost relevance in this selection in order to complement contents taught in those areas. It should be remarked that authentic material is always used in our practices, with the intention of teaching content from a discourse analysis perspective.

In 2007, engineering programmes had to reduce their length to five years. Therefore, contact hours were either reduced or eliminated in many areas, English being one of them. The three curricular courses (180 hours) were reduced to two terms (120 hours / two 60hour courses). Thus, some content had to be adapted and re-distributed while some was eliminated. The English Department found that preparing an A1 user with only two curricular courses became quite an ambitious objective. With the intent of overcoming this hurdle, the distribution of content that followed this change entailed focusing on oral competence in an academic environment in the first level and reading authentic genre exemplars and writing contextualized texts in the second level.

The English I course includes genres such as forms, schemes of studies, timetables, leaflets, brochures, web pages, surveys, reports, ads, emails, CVs, letters, job interviews and others.

The English II course, on the other hand, includes genres such as reports, fact files, newspaper articles, biographies, history files, oral presentations in engineering and others. The research article, its sections, rhetorical functions, the IMRD structure, abstract and title are explored in detail. This task includes many activities that are uploaded to the digital classroom. Further interaction provides opportunities for error analysis performed synchronically in the classroom with significant results, both in accreditation and in terms of the students' satisfaction.

To complement reduced teaching-learning contact hours, some courses were designed to meet specific requirements. A case in point was an intensive five-hour seminar on poster presentation as a research genre, delivered in 2009 to fifth-year engineering students who were presenting their research at a scientific meeting. A course on academic genres was also offered in 2009. It was addressed to undergraduate research grantees as an extracurricular voluntary activity. This course had a high enrollment rate but due to lack of time only four students completed it. This fact demonstrates great interest in academic literacy, but a demanding curricular schedule deters students from adhering to extracurricular activities.

Asof2012, engineering $\mathrm{PhD}$ programadministrators realized that $\mathrm{PhD}$ candidates were in strong need of a writing course for producing their $\mathrm{PhD}$ theses and papers for publications. An L1 Discourse Analysis specialist was invited to deliver these courses. This was the kairotic moment to negotiate the implementation of writing courses for our undergraduates. As a result, the specialist was invited to teach our undergraduate students as well. These courses deal with writing in L1 from a genre analysis perspective, in line with our English courses pedagogical practices. Students have attended them ever since 2012 (except for 2013) and found class dynamics and tasks highly relevant.

A summary of all the activities concerning academic literacy in L1 carried out in the Facultad de Ciencias de la Alimentación are shown in Table 1.

\begin{tabular}{|l|l|l|}
\hline $\begin{array}{l}\text { Date } \\
(\mathbf{m m} / \text { yyyy })\end{array}$ & Hours & Seminar \\
\hline $10 / 2012$ & $50 \mathrm{~h}$ & $\begin{array}{l}\text { Research writing in Engineering, } \\
\text { Science and Technology UNER } \\
\text { PhD Program }\end{array}$ \\
\hline $10 / 2012$ & $10 \mathrm{~h}$ & $\begin{array}{l}\text { Academic writing for Food En- } \\
\text { gineering undergraduates }\end{array}$ \\
\hline
\end{tabular}




\begin{tabular}{|l|l|l|}
\hline $06 / 2014$ & $50 \mathrm{~h}$ & $\begin{array}{l}\text { Tools for PhD theses writing. } \\
\text { Engineering, Science and Tech- } \\
\text { nology UNER PhD Program }\end{array}$ \\
\hline $06 / 2014$ & $10 \mathrm{~h}$ & $\begin{array}{l}\text { Writing tools for engineering } \\
\text { undergraduate genres. }\end{array}$ \\
\hline $06 / 2014$ & & $\begin{array}{l}\text { Talk and workshop on academic } \\
\text { genres in Engineering, addressed } \\
\text { to teachers at Facultad de Cien- } \\
\text { cias de la Alimentación, UNER }\end{array}$ \\
\hline $\begin{array}{l}08-09- \\
11 / 2015\end{array}$ & $30 \mathrm{~h}$ & $\begin{array}{l}\text { Writing tools for engineering } \\
\text { undergraduate advanced genres }\end{array}$ \\
\hline $\begin{array}{l}08-09- \\
11 / 2015\end{array}$ & $50 \mathrm{~h}$ & $\begin{array}{l}\text { Tools for paper writing in engi- } \\
\text { neering journals. Engineering, } \\
\text { Science and Technology UNER } \\
\text { PhD Program }\end{array}$ \\
\hline
\end{tabular}

Table 1. Academic literacy seminars in L1 delivered at the Facultad de Ciencias de la Alimentación - UNER - PhD and Food Engineering programmes.

It has to be remarked that these undergraduate seminars have been a component of the designed activities for an interdisciplinary research project focused on Food Engineering students written production. In 2012, the engineers teaching Formulación $y$ Evaluación de Proyectos and the English II professor met to discuss a shared concern and find a solution to the problem students face when they have to write their final project. This fact became visible as both titles and abstracts are uploaded to the university website once the theses are passed and defended. It was observed that these titles included very little information about the actual content of the study and the abstracts did not meet register expectations. Thus, a research project was designed and developed. The study included pedagogical interventions with the objective of activating prior or antecedent genre knowledge (Artemeva, 2010) as well as transferring strategies to Spanish. Previous studies have demonstrated that generic competence may be transferred to L1 (Noceti, A. \& Benedetti, M., 2008).

As regards research activities, it is worth noting that academic genres, their access and production have always been our concern. A service provided by members of the Language Department to professors, researchers, $\mathrm{PhD}$ candidates and students is assistance in translation and edition of papers for publication. It should be remarked that the research papers produced - and eventually published in prestigious journals as well as the outcomes of our research studies have a strong impact on our pedagogical practices. Research activities as such started in 1998, when the first research project was designed and accepted. The first project was titled "English in Scientific Communication in Food Sciences: pragmatic implications of a genre based approach." It was carried out by a team of English teachers and completed in $2001 .{ }^{11}$ From a genre analysis approach that included views from the New Rhetoric school, a corpus of 30 research articles in the field of food science were analyzed. The rhetorical structure as well as the characteristic linguistic traits used by experts to instantiate this genre were identified. These selections were justified by social context requirements. Citation in the text was explored to determine the efficacy of genre analysis in the study of recurrent linguistic phenomena. Results suggested that both generic structure and intertextuality may raise awareness of the rhetorical engineering required to produce this genre in addition to the linguistic strategies potential authors may select to textualise knowledge. As a result of this project, the generic structure of research articles in the field was designed as can be seen in Figure 1.

\begin{tabular}{|l|l|}
\hline MOVIMIENTO 1 & Establecimiento del campo \\
\hline MOVIMIENTO 2 & Revisión de estudios previos \\
\hline MOVIMIENTO 3 & Creación del espacio para la nueva investigación \\
\hline MOVIMIENTO 4 & Presentación de la nueva investigación \\
\hline MOVIMIENTO 5 & Descripción del proceso de recolección de muestras \\
\hline MOVIMIENTO 6 & Descripción del tratamiento de las muestras \\
\hline MOVIMIENTO 7 & $\begin{array}{l}\text { Descripción de las determinaciones físico-químicas y de las evaluaciones } \\
\text { sensoriales }\end{array}$ \\
\hline MOVIMIENTO 8 & Descripción del tratamiento estadístico de los datos \\
\hline MOVIMIENTO 9 & Información metodológica \\
\hline MOVIMIENTO 10 & Presentación de resultados \\
\hline MOVIMIENTO 11 & Explicación de resultados \\
\hline MOVIMIENTO 12 & Interpretación de resultados \\
\hline MOVIMIENTO 13 & Evaluación de resultados \\
\hline MOVIMIENTO 14 & Referencia a investigaciones previas \\
\hline MOVIMIENTO 15 & Limitaciones en los resultados \\
\hline MOVIMIENTO 16 & Recomendaciones/ espacio para nuevos estudios \\
\hline MOVIMIENTO 17 & Conclusión \\
\hline \\
Movimientos de la estructura genérica del artículo experimental de investigación en las Ciencias \\
de la Alimentación (Benedetti \& Noceti, 2000)
\end{tabular}

Fig. 1. Research articles generic structure in Food Science

In 2014, another research project was submitted, accepted and funded by the Science and Technology Department, UNER. The interest in improving undergraduates' writing skills fostered an interdisciplinary study: Optimization of Titles of 
Academic Genres Production by Awareness-raising of the Rhetorical Function. The research team is constituted by English teachers and the engineers who teach "Project Formulation and Evaluations". ${ }^{12}$ This project includes joint pedagogical actions between two areas, Project Design and Assessment and English II Course, with the objective of facilitating the development of adequate communicative strategies to produce and distribute knowledge in higher education environments. In addition, it is expected that the acquired communicative competence will meet publication requirements, both in Spanish and English. These actions specifically foster the production of academic genres by students in the School of Food Science, UNER. Titles of the final project (thesis) as well as the rhetorical function performed by them are the focus of the study. This limitation was based on the identification of difficulties students have to process, compact and produce information and distribute knowledge. Results have shown that joint actions and the implementation of writing courses for undergraduates have facilitated academic genre production. As a consequence, a further objective is designing a curricular writing course, which may involve new schemes of studies. This fact may lead to negotiations and decisions at the institutional macro level.

In 2014, the FoodInnova2014 International Conference was organized by the Facultad de Ciencias de la Alimentación together with the Universidad Politécnica de Valencia (Spain), and held in Concordia with most faculty professors and students participating and contributing with their research. A poster, "Interdisciplinarity at work: Engineers and Linguists join efforts to optimize undergraduate written production," accounted for the advances in the previously mentioned joint research project and was included within the Engineering and Education area. This was an excellent opportunity for students to participate, collaborate and actually see an academic event and the different genre systems enacted during its development

As mentioned above, the activity performed as "literacy brokers" (Lillis, T \& Curry, M.J., 2006) has encouraged us to further explore the research article. The "distillatation" (Swales, 1990) of the information scientists in our area perform to encapsulate their work and advertise their findings in the titles has been a very strong focus of attention (Noceti, 2012).

\section{Facultad de Ingeniería}

In this section, we will describe the actions that have been carried out, both in L1 and in L2 (English), to foster the development of academic literacy at the Facultad de Ingeniería.

It is important here to highlight that the Facultad de Ingeniería pledged to carry out a strategic plan for advancing excellence in the College's Self-Assessment Report presented to the National Commission for University Evaluation and Accreditation (CONEAU) in 2013. The general objective of the "curriculum and pedagogical improvement plan" is to strengthen aspects related to teaching methods and the learning process in the Bioengineering curriculum. One of its specific goals is to strengthen classroom practices aimed at developing oral and written skills in the students. Some of the activities described below are a consequence of this strategic plan.

Every year, the colleges of the UNER offer a month-long leveling entrance course in the face-toface format to all the beginners. During this period, students not only revise concepts from the core disciplines in their chosen programme (mathematics, physics and chemistry in our case), but also carry out activities that connect them to life at the university (its history, its organization and main regulations, the students' union, graduate and professional profiles, among others). This first attempt to help students overcome strangeness and communication barriers and to address issues of identity and belonging has as its corollary an oral presentation of the written work they produce during the course. This activity paves the way for other similar oral presentations the students are asked to give in forthcoming subjects and aims at fostering the development of interpersonal skills such as effective communication and team work.

The development of academic literacy has been a matter of longstanding concern for the Facultad de Ingeniería. This is why the Institution decided 
to take a step forward and a subject called Reading Comprehension and Writing (Comprensión Lectora y Producción Escrita) was included in the Licenciatura en Bioinformática curriculum. Some years later, when redesigning the 1997 Bioengineering curriculum, the subject was also included in the new 2008 Bioengineering programme. Moreover, it is also part of the Tecnicatura Universitaria en Producción de Medicamentos curriculum (a short-term undergraduate programme that offers training on how to become a pharmacy technician) that has been offered since 2013. In all such cases, it is a compulsory subject that is taught in the first year (84 hours).

The aim of the course is to develop academic reading and writing skills in L1 and to provide students with opportunities for vocational reflection. Three main activities are carried out during the year. In the first place, students are challenged to prepare a monograph on a topic related to their study programme (basic sciences, biomedical technology, installations and medicine) in small groups. From a pedagogical point of view, instances of feedback to evaluate students' learning progress by means of formative assessment (Black \& William, 1998) have been introduced. Learners are guided during the writing process and, on every occasion, feedback is provided and precise observations as regards how to overcome particular difficulties are made. This activity, in a similar fashion to the leveling course described earlier, is completed with an oral presentation of the findings. Secondly, the group visits the Science Interactive Museum (Museo Interactivo de Ciencias "Puerto Ciencia") ${ }^{13}$ that belongs to the Facultad de Ingeniería and, thirdly, students watch the presentation of final projects, the culminating experience of the study programme. These activities help first-year students understand their relationship to their programme of study and, in many cases, strengthen their motivation. Moreover, they are ideal opportunities to ask the students to write reports based on what they have seen and experienced, a genre that they will need to master in their professional settings. It is worth mentioning that the team in charge of both the leveling course and Reading Comprehension and Writing is a multidisciplinary group made up of specialists from the fields of education, communication, bioengineering and biology.

As for academic literacy development in L2 at the Facultad de Ingeniería, curriculum requirements establish a compulsory two-year English course (84 hours allotted to the first year and 56 hours to the second) for two degree programs: Bioengineering and Licenciatura en Bioinformática and a twosemester English course (90 hours) for the Tecnicatura Universitaria en Producción de Medicamentos. The goal of the courses is to equip students with the necessary tools to read specific genres produced by experts from the disciplines they are studying. To achieve this target, from a pedagogical point of view, an eclectic genrebased approach that integrates contributions from two traditions, i.e., English for Specific Purposes (ESP) represented by Swales (1990) and the North American Rhetoric studies represented by Miller (1984) and Freedman and Medway (1994) has been chosen. This approach allows for a perfect integration of a functional view of language and of concepts and considerations such as discourse centrality, communicative competence, strategic competence, functional communication and social interaction activities.

In the first level, students read texts from manuals and coursebooks, as these are generally rich in reformulations and examples; they usually use metadiscoursal markers and are accompanied by visual displays to facilitate comprehension. Other genres chosen for this level include interviews, book reviews and popularizing articles. In the second level - English II - the target genres are longer popularizing articles and the myriad communicative events (Swales, 1990) produced by the target discourse community that use specialized scientific discourse to reach their goals, i.e. research articles, patents and literature reviews (Waigandt, Soto \& Monzón, in press).

Since 2014, as part of an innovation project that is being carried out in English II, teachers changed traditional reading comprehension activities for tasks that serve both to check comprehension and to develop written and oral communication skills. The comprehension tasks aim at the production of three written genres in L1 (slide and poster presentations and 
abstracts). In addition, learners are expected to prepare and give oral presentations to a scientific or professional forum. These presentations are also performed in L1.

The tasks usually involve collaborative work and they increase in complexity, culminating in the preparation of an abstract in L1 for a research article written in L2. Towards the end of the year, learners are assigned a whole project, which involves a series of steps. These include: a) the selection of a topic of interest and the preparation of a dossier, which includes research articles published in high impact journals and a published patent on the same topic; $b$ ) the production of an abstract in which learners account for the problem tackled and the main findings of the articles analysed; and c) the design of a slide presentation, which is used while actually giving the presentation to an audience. It is important to highlight that these final presentations are based on a selection of reading material in L2 that is, in turn, based on a list of topics closely related to the main subjects covered in the study programmes, which leads the students to integrate academic practices and knowledge areas.

The programmes of study at the Facultad de Ingeniería are interdisciplinary and draw together professors and professionals from different disciplines that, more often than not, do not have pedagogical training. As an answer to this issue, a Pedagogical Training Programme was created in 2006 based on the belief that higher education requires reflective practice and that reflection must be carried out in a specific institutional space. The Programme is free and voluntary for the college staff.

Since their creation, on average 3.5 professional development courses have been offered each year with a high attendance rate. According to the information provided by surveys sent out by the Programme, participants have shown satisfaction not only with the topics dealt with (assessment, innovative pedagogical approaches, higher education issues, reading and writing to learn in the disciplines, among others), but also with the significant effects the discussions have upon their practices. In 2012, a specialist from the GICEOLEM, Mg. Graciela Fernández, carried out a workshop on reading and writing in higher education to learn in the disciplines that aroused interest in scholars from a variety of disciplines.

In this regard, it is worth mentioning that an interdisciplinary team is carrying out research that involves writing to learn practices in subjects such as vectorial calculus and differential equations (Añino et al., 2015) since 2008. The team has gradually introduced formative assessment into an engineering mathematics course in which only summative assessment had been traditionally used. Within an action research project, the changes involved a shift from an assessment system based on midterm tests, final exams and laboratory assignments to a new system that focuses on written reports that are orally presented in class, giving rise to open discussions in which peer, self and teacher assessment are combined. Students are also asked to submit drafts of their laboratory assignments to receive feedback from teachers. During the implementation of the project, an interesting link has been established between formative assessment and the WAC/WAD movements that promote writing across the curriculum/ in the disciplines, which has proved to be a powerful engine for learning.

Last, but not least, thanks to a joint effort of five Argentine national universities - the Universidad Nacional de Quilmes, the Universidad Nacional de General Sarmiento, the Universidad Nacional del Centro de la Provincia de Buenos Aires, the Facultad de Filosofía y Letras belonging to the Universidad de Buenos Aires and the Universidad Nacional de Entre Ríos - Professor Charles Bazerman visited Argentina in June 2014. As part of his visit to our country, Dr. Bazerman travelled to Entre Ríos to participate in the Jornadas de capacitación sobre lectura y escritura en la universidad that took place in Oro Verde on June 18 \& 19, 2014. More than seventy teachers and researchers attended the meeting. Twenty-two presentation $s^{14}$ on writing were given as part of the program that also included Dr. Bazerman's plenary conference "Writing in Higher Education in the Americas: A personal journey into data". As can be seen from records of the meeting, many other initiatives are being carried out at the National University of Entre Ríos, a fact that demonstrates the interest that scholars and researchers 
have in the development of academic literacy in higher education despite the fact that the Universidad Nacional de Entre Ríos is a small and relatively young state university.

\section{Conclusion}

In this article we have described both the Argentinean state higher education system and some of the difficulties it has been facing (high dropout rates and low graduation rates) in recent decades. The causes of these issues are varied and elusive; so we have focused our attention on the different student profiles that, from our point of view, present challenges to the traditional ways in which teaching has been provided in this educational level.

Then we have moved on to refer to the actions that have been taken in the Argentinean state higher education system to foster the development of academic literacy. It is clear that higher education institutions have undertaken the responsibility of addressing academic literacy development and that they are helping students cope with the enculturation process from different perspectives. We believe that these initiatives have paved the way for scholars and institutions who are becoming interested in designing programmes to improve students' academic literacy development and learning outcomes.

We have lastly described the activities that have been undertaken in the field of literacy development at the Facultad de Ciencias de la Alimentación and the Facultad de Ingeniería belonging to the Universidad Nacional de Entre Ríos in order to facilitate the acquisition of academic reading and writing both in L1 and L2. This account provides enough evidence that in our country and especially in our university there has been considerable concern over the development of academic literacy at all levels (beginners, first year to advanced students and graduates). Unfortunately, and due to the fact that in most of the cases the initiatives described have been individual or bottom-up (a teacher or group of teachers) rather than institutional or topdown initiatives, their outcomes have been measured mainly through feedback from students (surveys) and cannot be contrasted against institutional academic literacy diagnostic assessment results for comparison. When the initiatives are carried out within a research project, the outcomes are assessed by means of a national peer review process that ensures quality. In this case, the research project report must include publications of results in international peer-reviewed journals.

The initiatives described in the previous sections have had several implications for the question of access and equity that characterize the Argentinean higher education system. Some of our programmes seek to minimize the differences between beginners that are a result of different first language-literacy levels and experiences which are closely tied to social background and culture-specific patterns of interaction. Many students who choose our engineering programmes come from other provinces and even from other Latin American countries and, in many cases, have attended schools in less affluent areas with few resources and less qualified teachers. These students, more often than not, do not have a family history of academic participation, nor strong social networks in postsecondary education. In fact, they come to university without the knowledge that is needed to learn about college, how to be admitted, how to gain financial aid, and how to succeed in the dominant culture classes. For these students, academic literacy development plays a key role for social inclusion. On the other hand, in the case of advanced students, graduates and academic staff who wish to pursue further studies in our country or abroad and/or to publish their research results in high impact journals, our programmes are an access gate to their international discourse community. In this sense, we believe that academic literacy development in more than one language has significant international implications for universities in Argentina if they are to play an equal role in the higher education international scenario.

If the debate nowadays is about how the issue must be approached (Carlino, 2013), the challenge may be to engineer initiatives that best respond to local needs with full institutional support. We believe that academic literacy should be addressed comprehensively; that is, it must involve all institutional actors and support must be carried out throughout the levels. Our opportunity 
is to get more support from our university and make these individual initiatives become sustainable, i.e., independent of the agenda of the council in power in the future. In this way, the quantity and quality of change in individual teaching and research may spur change in the rest of the colleges that make up the Universidad Nacional de Entre Ríos and, therefore, trigger institutional awareness and change.

\section{Notes}

1. Programa Nacional de Becas Bicentenario: http:// www.becasbicentenario.gov.ar/

2. Instituto Autárquico Becario Provincial: http://www. institutobecario.gov.ar/

3. www.unesco-lectura.univalle.edu.co/

4. Grupo para la Inclusión y Calidad Educativas a través de Ocuparnos de la Lectura y la Escritura en todas las Materias. Available at: https://sites.google.com/site/ giceolem2010/

5. The translation is ours.

6. http://www.ungs.edu.ar/prodeac/

7. www.uner.edu.ar

8. http://www.bioingenieria.edu.ar/referencia/eventos/ libro_resumenes_jornadas_bazerman.pdf

9. http://www.confedi.org.ar/sites/default/files/ documentos_upload/Cuadernillo\%20de\%20 Competencias\%20del\%20CONFEDI.pdf

10. http://portales.educacion.gov.ar/spu/calidaduniversitaria/plan-estrategico-de-formacion-deingenieros-2012-2016/

11. http://proyectos.uner.edu.ar/

12.http://proyectos.uner.edu.ar/aplicacion. php?ah=5691732c1873f\&ai=gestion_extinv||23000105

13. http://puertociencia.bioingenieria.edu.ar/

14. The book of abstracts can be downloaded from http:// www.bioingenieria.edu.ar/referencia/eventos/libro_ resumenes_jornadas_bazerman.pdf

\section{References}

Alzari, I., Brown, A., Coppolecchia, F., Escandar, P., D’Alessandro, J., Moris, JP., Trincheri, M. (2014). Manual de escritura para carreras de humanidades. Buenos Aires: Editorial de la Facultad de Filosofía y Letras.
Amieva, R.L. (2014). Metáforas del cambio educativo: los sistemas de tutorías en las facultades de ingeniería. Revista Argentina de Enseñanza de la Ingeniería, 6, 7-13. Retrieved from: http://www.ing.unrc.edu.ar/raei/ archivos/img/arc_2014-05-02_20_21_55-Trabajo\%20 00.pdf

Añino, M.M., Perassi, M., Merino, G., Ravera, E., Pita, G., Miyara, A. \& Waigandt D. (2012). Mejorar la enseñanza y el aprendizaje de la Matemática en Bioingeniería: Un desafío asumido desde la investigación-acción. Revista Argentina de Enseñanza de la Ingeniería, 1, 3545. Retrieved from: http://www.ing.unrc.edu.ar/raei/ archivos/img/arc_2012-03-16_20_04_57-214.pdf

Añino, M.M., Merino, G., Miyara, A., Perassi, M., Pita, G., Ravera, E., Theler, A. \& Waigandt, D. (2015). La Enseñanza de la Matemática en Bioingeniería de las Investigación-Acción. Una Reseña. Ciencia, Docencia y Tecnología. 5, 137-163.

Arnoux, E. (1998). Talleres de lectura y escritura. Buenos Aires: Eudeba.

(2006). Incidencia de la lectura de pares y expertos en la reescritura del trabajo de tesis. Revista de Linguística Teórica y Aplicada, 44(1). http:// selloeditorial.udec.cl/rla-44-1/

(2008). Lectura y escritura en el primer año universitario: investigaciones $\mathrm{y}$ orientaciones pedagógicas. In Badano, M. del R., Bearzotti, N. \& Berger, S. (Comp.) Políticas, prácticas y saberes sobre el ingreso a la universidad. Paraná: Universidad Autónoma de Entre Ríos \& Universidad Nacional de Entre Ríos.

(Ed.). (2009) Escritura y producción de conocimientos en las carreras de postgrado. Buenos Aires: Santiago Arcos.

(2011). La escritura de tesis: apoyos institucionales y propuestas pedagógicas. In Vázquez, A., Novo, M. del C., Jakob, I. \& Pelliza, L. Lectura, escritura y aprendizaje disciplinar (pp. 25-39). Córdoba: UniRío editora. https://www.unrc.edu.ar/unrc/digtal/libro_ jornadas_unesco_unrc_2010.pdf

Arnoux, E., Alvarado, M., Balmayor, E., Di Stéfano, M., Pereira, C. \& Silvestri, A. (1996). El aprendizaje de la escritura en el ciclo superior. In Z. Solana (Comp.), Adquisición de la escritura (199-234). Rosario: Ediciones Juglaría.

Artemeva, N. (2008). Toward a unified social theory of genre learning. Journal of Business and Technical Communication, 22(2), 160-185.

Artemeva, N. \& Fox, J. (2010). Awareness Versus Production: Probing Students' Antecedent Genre Knowledge. Journal of Business and Technical 
Communication. SAGE Publications. DOI: $10.1177 / 1050651910371302$.

Bazerman, C. (1988). Shaping Written Knowledge: The Genre and Activity of the Experimental Article in Science. WAC Clearinghouse Landmark Publications in Writing Studies: http://wac.colostate.edu/books/ bazerman_shaping/ Originally Published in Print, 1988. Madison, Wisconsin: University of Wisconsin Press.

Bazerman, C., Little, J., Bethel, L., Chavkin, T., Fouquette, D. \& Garufis, J. (2005). Reference guide to writing across the curriculum. West Lafayette: Parlor Press.

Benedetti, M., Noceti, A., Weller, P. (2000). Estructura Genérica del Artículo Experimental de Investigación en las Ciencias de la Alimentación. Revista de Ciencia y Técnica, UNER.

Black, P., \& Wiliam, D. (1998). Assessment and classroom learning. Assessment in education: Principles, Policy \& Practice, 5(1), 7-74.

Bolivar, A. \& Parodi, G. (2015). The Routledge Handbook of Hispanic Applied Linguistics. New York: Taylor and Francis.

Bourdieu, P. (1977). Cultural Reproduction and Social Reproduction Bourdieu and Passeron. In Richard K. Brown (Ed.), Knowledge, Education and Cultural Change. London: Tavistock.

Brown, J. S., Collins, A. \& Duguid, P. (1989). Situated cognition and the culture of learning. Educational Researcher, 18(1), 32-42.

Carlino, P. (2003). Alfabetización académica: Un cambio necesario, algunas alternativas posibles. Educere, Revista Venezolana de Educación, 6(20) 409- 420. Retrieved from http://www.saber.ula.ve/ bitstream/123456789/19736/1/ articulo7.pdf

(2006). Concepciones y formas de enseñar escritura académica. Un estudio contrastivo. Signo\&Seña, 16, 71-117. http://goo.gl/qLMpWm

(2012). Who Takes Care of Writing in Latin American and Spanish Universities? In Thaiss, C., Bräuer, G., Carlino, P., Ganobcsik-Williams, L. and Sinha, A. (Eds.), Writing Programs Worldwide: Profiles of Academic Writing in Many Places. Perspectives on Writing (pp. 485-498). Fort Collins, Colorado: The WAC Clearinghouse and Parlor Press. http://wac. colostate.edu/books/wpww/chapter41.pdf

(2013). Alfabetización académica diez años después. Revista Mexicana de Investigación Educativa, 57, 355-381. Retrieved from http://www.comie.org. $\mathrm{mx} / \mathrm{v} 1 /$ revista/portal.php?idm $=\mathrm{es} \& \mathrm{sec}=\mathrm{SC} 01 \& \mathrm{sub}=\mathrm{S}$ BA\&criterio $=\mathrm{N} 057$
(2014). Se aprende muy diferente una materia si se lee y escribe sobre sus temas. In S. Serrano \& R. Mostacero (Eds.). La escritura académica en Venezuela: Investigación, reflexión y propuestas (pp. 27-47). Mérida, Venezuela: Universidad de Los Andes.

Chalmers, D. \& Fuller, R. (1996). Teaching for learning at university. Londres: Kogan Page.

Chiroleu, A. \& Marquina, M. (2010). Argentina. In Vlaardinger Brock, B. \& Taylor, N. (Eds.). Getting into varsity - Comparability, convergence and congruence. New York: Cambria Press Inc.

Council of Europe, Language Policy Unit, Strasbourg .Common European Framework Of Reference For Languages: Learning, Teaching, Assessment. https://www. coe.int/t/dg4/linguistic/Source/Framework_EN.pdf

Freedman, A. (1994). "Do as I Say': The relationship between teaching and learning new genres", in A. Freedman y P. Medway (eds.), Genre and the new rhetoric. London: Taylor and Francis.

Freedman, A. \& Medway, P. (eds.). (1994). Genre and the New Rhetoric. London: Taylor and Francis.

Gee, J. (1990). Social linguistics and literacies: ideology in discourses. Brighton: Falmer Press.

Lave, J. \& Wenger, E. (1991). Situated Learning Legitimate Peripheral Participation. Cambridge: CUP.

Lea, M. \& Street, B. (1998). Student writing in higher education: An academic literacies approach. Studies in Higher Education, 23(2), 157-172.

Lillis, T \& Curry, M.J., (2006): Professional Academic Writing by Multilingual Scholars Interactions with Literacy Brokers in the Production of English-Medium Texts. Written Communication, 23(1), 3-35.

Marginson, S. \& Mollis, M. (2001). The door opens and the tiger leaps. Theories and reflexivities of comparative education for a global millennium. Comparative Education Review, 45(4).

Miller, C. (1984). Genre As Social Action. Quarterly Journal of Speech, 70, 151-167.

Moyano, E., \& Natale, L. (2012). Teaching academic literacy across the university curriculum as institutional policy. The case of the Universidad Nacional de General Sarmiento (Argentina). In C. Thaiss, G. Bräuer, P. Carlino, L. Ganobcsik-Williams \& A. Sinha (Eds.), Writing Programs Worldwide: Profiles of Academic Writing in Many Places (23-34). West Lafayette, Indiana: Parlor Press \& WAC Clearinghouse. Retrieved from: http://wac.colostate.edu/books/wpww/chapter2.pdf

Narvaja de Arnoux, E., Di Stefano, M. \& Pereira, C. (2002). La lectura y la escritura en la universidad. Buenos Aires: Eudeba. 
Narvaja de Arnoux, E. \& Bein, R. (Eds.). (2015). Políticas lingüísticas y enseñanza de lenguas. CABA: Editorial Biblos.

Noceti, A. \& Benedetti, M. (2008). Disciplinary Identity Construction through Mastery of the Power Point Presentation Genre. Licenciatura en Inglés Thesis, FHUC, UNL. Supervisor: Daniel J. Fernández, MgS. Unpublished

Pipkin Embón, M. \& M. Reynoso (2010). Prácticas de lectura y escritura académicas. Córdoba: Editorial Comunicarte.

Purser, E., Skillen, J., Deane, M.; Donohue, J. \& Peake, K. (2008). Developing academic literacy in context. Zeitschrift Schreiben. Available at: http://ro.uow.edu. $\mathrm{au} / \mathrm{cgi} /$ viewcontent.cgi? article $=1243 \&$ context $=$ asdpap ers

Radloff, Alex (ed.) (1998). Communication-in-context. A Commonwealth Staff Development Funded Project. Perth: Curtin University of Technology.

Russell, D. (1990). Writing across the curriculum in historical perspective: Toward a social interpretation. College English, 52, 52-73.

(2002). Writing in the academic disciplines.

A curricular history. Carbondale y Edwardsville: Southern Illinois University Press.

Skillen, J., Merten, M., Trivett, N. \& Percy, A. (1998). The IDEALL approach to Learning Development: a model for fostering improved literacy and learning outcomes for students. Available at http://ro.uow.edu.au/cgi/ viewcontent.cgi? article $=1149 \&$ context $=$ asdpapers

SPU. (2013). Anuario de estadísticas universitarias. Buenos Aires: Secretaría de Políticas Universitarias. http://informacionpresupuestaria.siu.edu.ar/ DocumentosSPU/Anuario_2013.pdf

Street, B. (1993). The new literacy studies. Journal of Research in Reading, 16(2), 81-97.

Swales, J. (1990). Genre Analysis: English in Academic and Research Settings. Cambridge, UK: Cambridge University Press.

Waigandt, D., Soto, A. \& Monzón, S. (in press) Teaching Written, Oral and Mixed Academic Genres in an ESP Course at the Universidad Nacional de Entre Ríos. Paper presented at the VIII Simpósio Internacional de Estudos de Gêneros Textuais (São Paulo - Brazil September 2015). 